\title{
Distribution of Wall-bound Invertase during the Asexual Life-cycle of Neurospora crassa
}

\author{
By PATRICIA L. Y. CHANG* AND J. R. TREVITHICK \\ Department of Biochemistry, University of Western Ontario, London, Ontario, Canada
}

(Accepted for publication 17 September 197I)

SUMMARY

The association of invertase with Neurospora wall was studied biochemically in six cytologically distinct stages of the Neurospora asexual life-cycle: (i) conidia, (ii) mid-log phase [10 h old], (iii) post-log phase hyphae [ $8 \mathrm{~h}$ old], (iv) aerial mycelium [4 days old], (v) submerged mycelium [4 days old], and (vi) mycelium [ 2 days old] induced to form conidiophores. The percentages of total invertase activity found in the wall fraction were $8,18,23,8,2 \mathrm{I}$ and $\mathrm{I} 7$, respectively. The specific activities of the wall fraction were 3,85, I 20, 40, 24, and 74 units of invertase activity per milligram protein, respectively. Histochemical localization of invertase with an indirect immunofluorescent technique also showed that conidiophores had strong activity in their walls as well as in the cytoplasm and that vacuoles were devoid of any activity.

\section{INTRODUCTION}

Fungal development is usually accompanied by changes in enzyme activities (Zalokar, I959; Nagasaki, I968; Stine, 1969). A few mural exoenzymes in fungi are also present in amounts that vary with the age of the organism (Horikoshi \& Ikeda, 1965; Mahadevan \& Mahadkar, 1970). Since invertase [EC. 3.2.1.26, $\beta$-D-fructofuranoside fructohydrolase] is one of the mural exoenzymes found in Neurospora (Chang \& Trevithick, 1972) this report records its changing distribution in the wall fraction during the Neurospora asexual lifecycle, as represented by six cytologically distinct stages. A histochemical technique using indirect immunofluorescent staining was also used to elucidate finer details of invertase localization.

\section{METHODS}

Organism. Wild-type Neurospora crassa was grown on Fries minimal medium (Beadle \& Tatum, 1945), $2 \cdot 7 \%$ (w/v) galactose, and sodium succinate buffer $(0.04 \mathrm{M}, \mathrm{pH} 5.2)$.

Growth conditions. Conidia in large quantities were obtained by the method of Zalokar (I959) from 7-day cultures grown in a Fernbach flask containing $500 \mathrm{ml}$ of agar-solidified medium. Mid-log phase mycelium was obtained from cultures $(2 \mathrm{ml}$ of conidial suspension, extinction at $500 \mathrm{~nm}=20$, inoculated into $100 \mathrm{ml}$ of growth medium in a $250 \mathrm{ml}$ Erlenmeyer flask) grown at $30^{\circ}$ and agitated at a speed of $250 \mathrm{rev}$. $/ \mathrm{min}$ in a gyratory shaker bath. It was harvested after $10 \mathrm{~h}$ by filtration through a membrane filter (type HA, Millipore Corp., Massachusetts, U.S.A.). Post-log phase mycelium ( $\mathrm{ml}$ conidial suspension, extinction at $600 \mathrm{~nm}=20$, inoculated into $50 \mathrm{ml}$ culture medium in a $125 \mathrm{ml}$ Erlenmeyer flask) was similarly obtained after $18 \mathrm{~h}$ of incubation. Aerial and submerged mycelia were

* Present address: Biology Department, University of Waterloo, Waterloo, Ontario, Canada. 


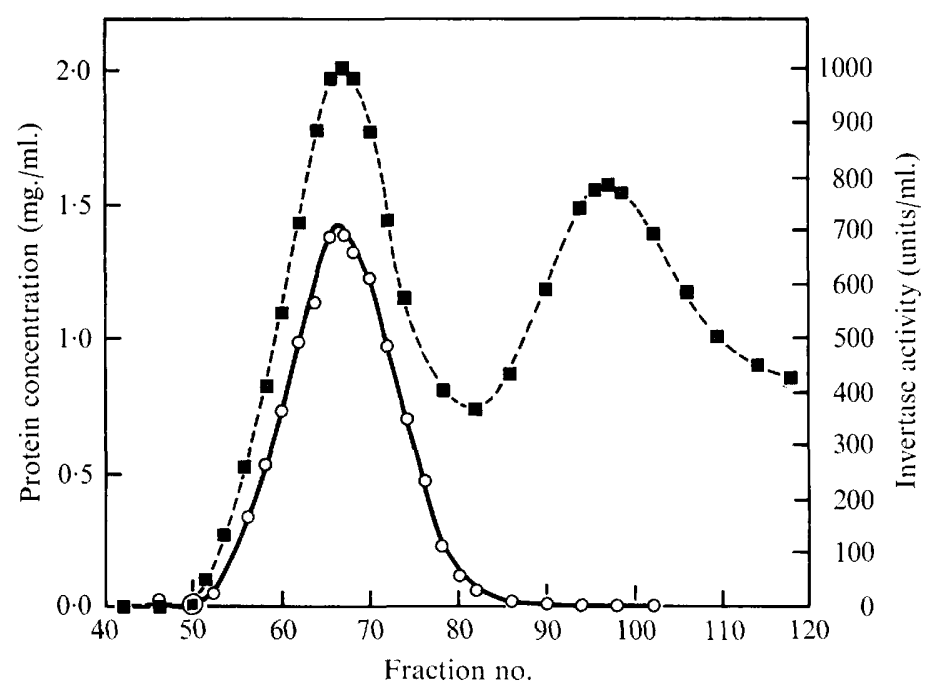

Fig. I. Purification of invertase by Sephadex G-20o chromatography. The conditions of the experiment are described in the text. The protein concentration is calculated from the extinction at $280 \mathrm{~nm}$ using the extinction coefficient of invertase $(\epsilon \mathrm{I} \% / \mathrm{I} \mathrm{cm}=18 \cdot 6)$ given by Metzenberg (I963a) and invertase activity was determined according to the method of Metzenberg (1962). One unit of invertase activity is defined as the amount of enzyme releasing I micromole of glucose from sucrose/ $\min$ at $37^{\circ}$. -- --, protein concentration; - $\mathrm{O}$-, invertase activity.

obtained according to the method of Zalokar (1959) from 4-day stationary culture (200 $\mathrm{ml}$ ). The mycelial mat on the surface of the culture medium in contact with air was designated as the aerial mycelium. The dispersed wisps of mycelium entirely submerged in the growth medium of the same flask were designated as the submerged mycelium. Mycelium from a 2-day shake culture $(50 \mathrm{ml})$ was induced to form conidiophores by starving thin mats of mycelium on moist filter paper at room temperature for $8 \mathrm{~h}$ (Stine \& Clark, 1967). About three mycelial mats, designated as 'conidiphores + mycelium', were obtained from $50 \mathrm{ml}$ culture and pooled for each experiment.

The invertase activity was determined by the method of Metzenberg (1962).

Determination of protein. Folin phenol reagent was used according to the method of Lowry, Rosebrough, Farr \& Randall (I95I). After the reaction was completed, samples with insoluble residues, e.g. walls, were centrifuged at $6000 \mathrm{rev} . / \mathrm{min}$ for $10 \mathrm{~min}$ in a GLC Sorvall Centrifuge before the supernatant fractions were taken for colorimetric readings. Bovine serum albumin dried overnight in a vacuum desiccator over $\mathrm{NaOH}$ was used as the standard.

\section{Immunofluorescent staining.}

(a) Preparation of antigen. Invertase was prepared from Neurospora crassa according to the method of Metzenberg ( $1963 a$ ). The final purification step with carboxymethyl cellulose column chromatography was replaced by G-200 Sephadex gel filtration which allowed almost $100 \%$ recovery of enzyme activity. A $3 \times 100 \mathrm{~cm}$ column of G-200 Sephadex was equilibrated with buffer B (sodium succinate buffer, $0.005 \mathrm{M}, \mathrm{pH} 5.0$, containing $0.00 \mathrm{I} \mathrm{M-}$ EDTA) for over $24 \mathrm{~h}$. The column was charged with about $100 \mathrm{mg}$ of protein dissolved in $\mathrm{I} .5 \mathrm{ml}$ of buffer A (sodium succinate buffer, $\mathrm{O}^{\circ} \mathrm{I} \mathrm{M}, \mathrm{pH} 5.0$, containing $0.00 \mathrm{I}$ M-EDTA). Elution with buffer B proceeded at a flow rate of $0.2 \mathrm{ml} / \mathrm{min}$ and $3 \mathrm{ml}$ fractions were collected. The whole operation was performed below $4^{\circ}$. 
Extinction at $280 \mathrm{~nm}$ and invertase activity of the eluted fractions were measured (Fig. I). All of the invertase activity was recovered from fractions 50 to 82. Disc-gel electrophoresis for detecting protein components and invertase activity was performed on some fractions by the method of Metzenberg (I964). A predominant single band of protein, coincident with invertase activity, was detected in fractions 59 to 67 . Faster moving bands of impurities appeared in fraction 76 .

(b) Preparation of anti-invertase serum. Electrophoretically pure invertase $(3 \mathrm{mg}$ in $\mathrm{I} \cdot 8 \mathrm{ml}$ of buffer B) dispersed in $\mathrm{I} .8 \mathrm{ml}$ Freund's complete adjuvant was injected subcutaneously into each of three rabbits, followed after eight weeks by a second injection of I $\mathrm{mg}$ invertase in $2 \mathrm{ml}$ phosphate buffered saline (PBS: $0.9 \%$ sodium chloride in $0.0 \mathrm{O} \mathrm{M}$ sodium phosphate buffer at $\mathrm{pH} 7 \cdot \mathrm{r}$ ). Rabbit serum was collected six days later by cardiac puncture and processed according to the method of Campbell, Garbey, Cremer \& Sussdorf (1963). The serum gave a single precipitin line against pure invertase by Ouchterlony's twodimensional diffusion test (Campbell et al. 1963). Samples were frozen and diluted 15 -fold with PBS before use.

(c) Staining procedure. The 'Sandwich technique' according to Nairn (1969) was used. Sections of mycelium ( $2 \mu \mathrm{m}$ thick) were cut in a cryostat at $-20^{\circ}$ and allowed to react with rabbit-anti-invertase serum. The antigen (invertase) -antibody (rabbit-anti-invertase immunoglobulin) complex so formed was allowed to react with a fluorescein-labelled goat-antirabbit immunoglobulin preparation. The invertase:rabbit antibody:goat antibody 'sandwich' complex was made visible by the fluorescein label when a u.v. light source was applied

\section{Table I. Invertase distribution in Neurospora crassa of different physiological stages*}

Neurospora cultures grown under different conditions were harvested. Mycelia were collected by filtration, washed with distilled water, blotted dry with filter paper to give the wet weight, and disrupted by sonic treatment. A sample of the mycelial homogenate was taken for total cellular activity determination. The rest of the sample was used for wall preparation by washing with PBS, $\mathrm{I} \%(\mathrm{v} / \mathrm{v})$ Triton X-Ioo, $\mathrm{M}-\mathrm{NaCl}$ (twice) and PBS (twice) successively. The wall fractions were recovered by centrifugation at $100 \times g$ for 15 min each time.

$$
\begin{aligned}
& \text { Stationary culture- } 4 \text { days } \\
& \text { (200 ml) }
\end{aligned}
$$

\begin{tabular}{|c|c|}
\hline$\underbrace{\text { Aerial }}_{\text {mycelium }}$ & $\begin{array}{c}\text { Submerged } \\
\text { mycelium }\end{array}$ \\
\hline sk + Bottle & Bottle + \\
\hline
\end{tabular}

A. Total cellular activity
(i) Wet wt (g)
(ii) Total activity
$3 \cdot 46$
(iii) Specific activity!l $\quad 0.63$

0.35
203
6.5

0.29
179
8.7

0.69
617
10.7

I $\cdot 32$
963
II $\cdot 0$

$\begin{array}{cc}0.26 & 0.39 \\ 429 & 671 \\ 14.5 & 14.5\end{array}$

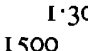
B. Wall fraction
(i) Total activity $\$$ I I 7
(ii) Specific activity.|

I I 7
$2 \cdot 93$

$\begin{array}{cc}37.6 & 4 \mathrm{I} \cdot 7 \\ 85.4 & \mathrm{I} 20 \\ 18.5 & 23.4\end{array}$
$43 \cdot 7$
$40 \cdot 8$
$89 \cdot 6$
$40 \cdot 7$

$\begin{array}{lr}96 \cdot \text { I } & \text { I } 37 \\ 22 \cdot I & 26 \cdot 2 \\ 22 \cdot 4 & 20 \cdot 5\end{array}$
260
74
$7 \cdot 0$
$9 \cdot 3$
$22 \cdot 4$
20.5
$17 \cdot 4$

$$
\frac{\mathrm{B}(\mathrm{i})}{\mathrm{A}(\mathrm{ii})} \times 100 \%
$$

* All entries are the means of duplicate experiments except $\dagger, \downarrow$, and those pertaining to 'conidia'. Samples in each experiment were assayed in duplicate. Deviations of experimental data from the mean values were generally less than $10 \%$.

$\dagger$ Culture grown in a 21 Erlenmeyer flask.

$\ddagger$ Culture grown in a $500 \mathrm{ml}$ Roux bottle.

$\S$ Total activity is expressed in units of invertase activity, defined as $\mu$ mole glucose liberated from sucrose/ $\min$ at $37^{\circ}$.

I! Specific activity is expressed as units of invertase activity/mg protein. 
to the tissue section under a microscope. The procedure and modifications of this method have been described in detail by Chung \& Trevithick (1970). Controls using (i) normal rabbit serum, (ii) anti-invertase rabbit serum previously adsorbed with purified invertase for $48 \mathrm{~h}$, and (iii) goat anti-rabbit serum directly on the tissue sections, showed negligible fluorescence under similar conditions.

\section{RESULTS}

The specific activity and percentage of invertase associated with the wall fraction varied significantly in the different phases of the Neurospora life-cycle. (Table I).

Both the percentage of total cellular activity and the specific activity of invertase in the wall fraction were lowest in conidia. During the log phase of growth lasting $\mathrm{I} 2$ to $\mathrm{I} 4 \mathrm{~h}$, two general trends of invertase distribution were evident: an increasing proportion of the cellular activity became incorporated into the wall fraction; specific activity of the wall-bound (mural) invertase also increased. Hence, the percentages of total cellular activity found in the wall fraction rose from $8 \%$ in the conidia to $18 \%$ in the mid-log phase mycelium and then to $23 \%$ in the post-log phase mycelium; the specific activity of the mural invertase also increased 30 -fold, and then 40 -fold, respectively, over that in the conidial wall fraction.

The effect of ageing on the distribution of invertase can be inferred from a comparison of mycelia in or near the $\log$ phase with mycelia in a 4 -day stationary culture. Specific activity of total cellular invertase showed an almost twofold increase in the stationary cultures, whereas the specific activity of the wall fraction showed a two- to fivefold decrease in these older cultures.

The effects of differentiation were demonstrated by the two populations of mycelia of the same age, i.e. the aerial mycelium and the submerged mycelium in the 4-day stationary culture. According to Zalokar (1959), morphological and biochemical differences occur as a result of such differentiation. Besides having different enzymic characteristics, the submerged or deep mycelium generally possessed more moribund features, such as vacuoles and fat globules, than the aerial or surface mycelium. The invertase distribution also varied in these mycelia. Specific activity increased (to $\mathrm{I} \cdot 5$ times) in total cellular invertase and decreased (to half) in the wall fraction of the more senescent submerged mycelium. Vacuoles were shown by indirect immunofluorescent staining to be devoid of invertase activity (Fig. 2).

In the 'conidiophores + mycelium' culture, invertase of high specific activity was found in the total mycelial homogenate as well as the wall fraction (Table I). However, since the major portion of the sample material consisted of undifferentiated hyphae rather than differentiated conidiophores, it was difficult to ascribe the high activities to the conidiophores per se on biochemical grounds alone. Histochemical staining by an indirect immunofluorescent technique showed that strong invertase activity was indeed apparent both in the cytoplasm and the walls of conidiophores (Fig. 3), thus giving some qualitative support to the gross biochemical data.

\section{DISCUSSION}

In Neurospora conidia; Eberhart (I96I) showed that part of the invertase was truly extracellular, i.e. washed away from the conidia with water. Metzenberg (I963 $b$ ) also showed that most of the conidial invertase was cell-bound exoenzyme, i.e. completely accessible to substrate, $\mathrm{H}^{+}$, and inhibitors in the medium. The peripheral localization of this enzyme was confirmed by Chung \& Trevithick (1970) with immunofluorescent staining on conidial sections. However, only $8 \%$ of the total cellular activity was. found in this report to be in the 

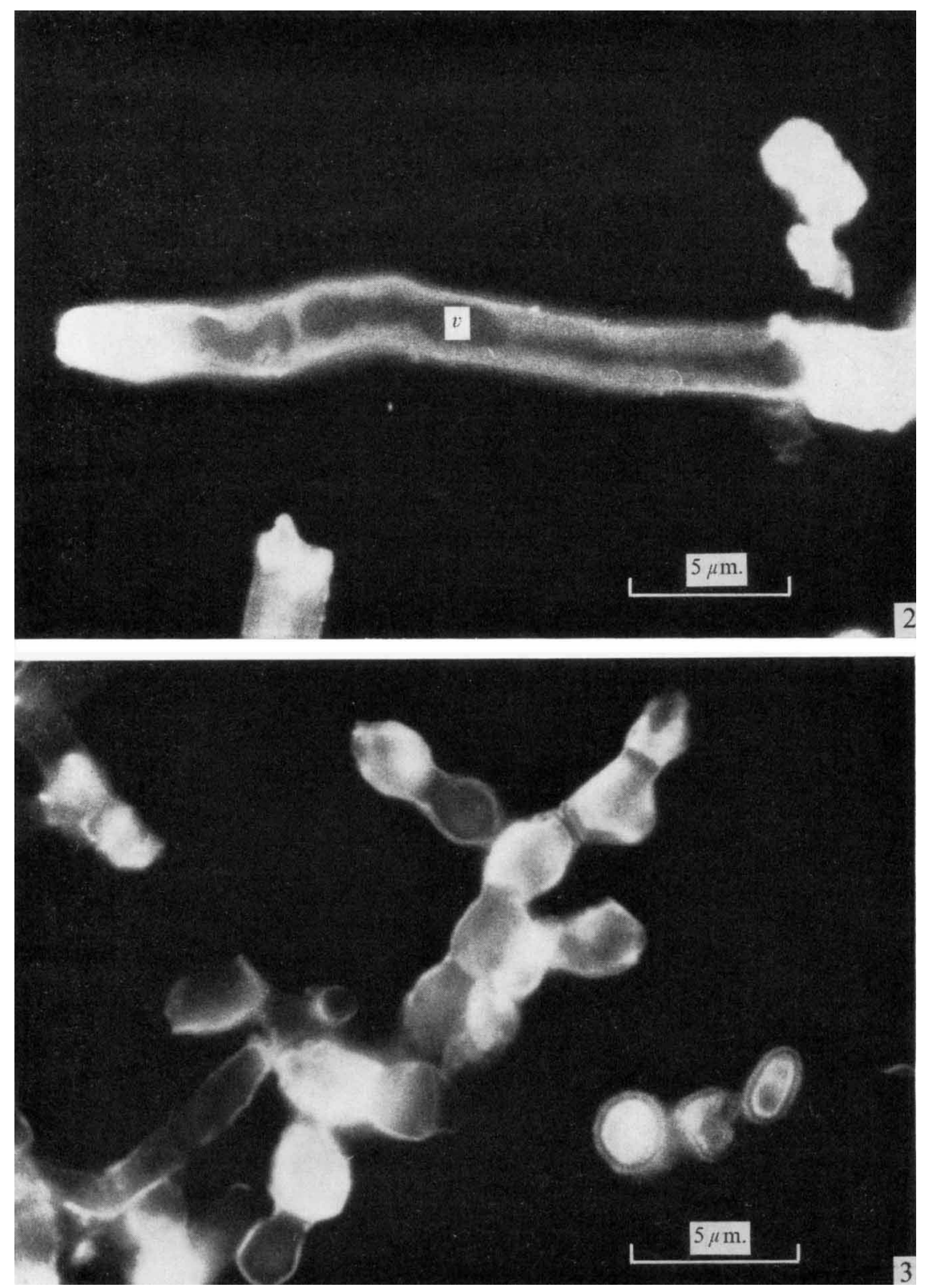

Fig. 2. Neurospora hypha ( $2 \mu \mathrm{m}$ thick) from submerged mycelium stained for invertase by an indirect immunofluorescent technique. Large vacuoles (v) were devoid of invertase activity.

Fig. 3. Neurospora conidiophores ( $2 \mu \mathrm{m}$ thick) stained for invertase with an indirect immunofluorescent technique. Strong invertase activity occurred generally in the cytoplasm and the walls. 
wall fraction, i.e. a mural exoenzyme. Therefore, most of the invertase activity must be free within the periplasmic space and/or associated with the outside of the plasma membrane.

The transition of Neurospora to a highly active metabolic state during germination of conidia and subsequent logarithmic growth is often accompanied by increased enzymatic activities in biosynthetic pathways (Stine, I968), in respiratory activities (Zalokar, I959; Weiss, I963), and in various hydrolytic reactions (Hill \& Sussman, 1964; Scott \& Metzenberg, 1970). The increase in specific activity of total cellular invertase as well as wall-bound invertase observed here probably reflects the active synthesis and secretion of this enzyme during the initial stages of the Neurospora life-cycle.

In the later stages of the Neurospora life-cycle, when senescence was brought about either by ageing or differentiation, specific activity of the total cellular invertase also increased. Since invertase is a derepressible enzyme (Metzenberg, 1962), such elevation of activity may have been caused by a relief from intracellular catabolite repression due to depletion of exogenous sugar supply, or a general reduction of metabolic activity.

The absence of invertase activity in Neurospora vacuoles (Fig. 2) contrasts with its presence in yeast vacuoles (Beteta \& Gascon, I97I). It has been suggested that the yeast vacuoles function similarly to the zymogen granules in the mammalian pancreas (Palade, Siekevitz \& Caro, I962). If so they would correspond more closely to 'secretory vacuoles' and would be quite different in nature from the moribund vacuoles in Neurospora hyphae.

In conclusion, significant changes of invertase activity were observed during the Neurospora life-cycle. Transition from dormancy to active growth was accompanied by increased specific activity of the total cellular invertase as well as of the wall-bound invertase. In cytologically older mycelia, either from ageing or differentiation, specific activity of the total cellular invertase was also higher than in the younger mycelia but their wall fractions did not show a concomitant increase.

The authors thank Dr C. F. Robinow, Dr D. B. Smith and Dr A. Wellman for helpful discussions during the course of this work. The assistance provided by a grant from the Medical Research Council of Canada is gratefully acknowledged. The paper formed part of a dissertation submitted by P.L.Y.C. in partial fulfilment of the requirements for the degree of Doctor of Philosophy, University of Western Ontario, Ontario, Canada.

\section{REFERENCES}

Beadle, G. W. \& Tatum, E. L. (1945). Neurospora. II. Methods of producing and detecting mutations concerned with nutritional requirements. American Journal of Botany 32, 678-686.

BeteTA, P. \& GASCON, S. (197I). Localization of invertase in yeast vacuoles. FEBS Letters 13, $297-300$.

Campbell, D. H., Garvey, J. S., Cremer, N. E. \& Sussdorf, D. H. (1963). Methods in Immunology, pp. 12-23, 143-149. New York: W. A. Benjamin.

Chang, P. L. Y. \& Trevithick, J. R. (1972). Release of wall-bound invertase and trehalase in Neurospora crassa by hydrolytic enzymes. Journal of General Microbiology 70, 13-22.

Chung, P. L. Y. \& Trevithick, J. R. (1970). Biochemical and histochemical localization of invertase in Neurospora crassa during conidial germination and hyphal growth. Journal of Bacteriology ro2, 423-429.

EBerHART, B. M. (196I). Exogenous enzymes of Neurospora conidia and mycelia. Journal of Cellular and Comparative Physiology 58, I I-I6.

Hill, E. P. \& Sussman, A. S. (1964). Development of trehalase and invertase activity in Neurospora. Journal of Bacteriology 88, I556-1 566.

HorikoshI, K. \& IKEDA, Y. (1965). Studies on the spore coats of Aspergillus oryzae. II. Conidia coat-bound $\beta$-glucosidase. Biochimica et biophysica acta ror, 352-357.

Lowry, O. H., Rosebrough, N. J., Farr, A. L. \& Randall, R. J. (I95I). Protein measurement with the Folin phenol reagent. Journal of Biological Chemistry 193, 265-275. 
MahadeVAN, P. R. \& MAHAdKAR, U. R. (1970). Role of enzymes in growth and morphology of Neurospora crassa: cell-wall-bound enzymes and their possible role in branching. Journal of Bacteriology ror, 94I-947.

METZENBERG, R. L. (I962). A gene affecting the repression of invertase and trehalase in Neurospora. Archives of Biochemistry and Biophysics 96, 468-474.

Metzenberg, R. L. (1963a). The purification and properties of invertase of Neurospora. Archives of Biochemistry and Biophysics roo, 503-51 I.

Metzenserg, R.L. (1963b) The localization of a $\beta$-fructofuranosidase in Neurospora. Biochimica et biophysica acta $77,455-465$.

METZENBERG, R. L. (1964). Enzymically active subunits of Neurospora invertase. Biochimica et biophysica acta 89, 291-302.

NAGASAKI, S. (1968). Cytological and physiological studies on phosphatases in developing cultures of Aspergillus niger. Journal of General and Applied Microbiology, Tokyo 14, 263-277.

NaIRN, R. O. (1969). Fluorescent Protein Tracing, 3rd edn, pp. I29-130, 147-148. Edinburgh: E. and S. Livingstone.

Palade, G. E., Siekevitz, P. \& Cro, L. G. (1962). Structure, chemistry, and function of the pancreatic exocrine cell. In The Exocrine Pancreas, pp. 23-55. Edited by A. V. S. De Reuck \& M. P. Cameron. Ciba Foundation Symposium. London: J. and A. Churchill.

SCOTT, W. A. \& Metzenberg, R. L. (1970). Location of aryl sulfatase in conidia and young mycelia of Neurospora crassa. Journal of Bacteriology 104, I254-I 265.

STINE, G. J. (1968). Enzyme activities during the asexual cycle of Neurospora crassa. II. NAD- \& NADPdependent glutamic dehydrogenases and nicotinamide adenine dinucleotidase. Journal of Cell Biology 37, 8I-88.

StiNe, G. J. (1969). Enzyme activities during the asexual cycle of Neurospora crassa. III. Nicotinamide adenosine diphosphate glycohydrolase. Canadian Journal of Microbiology 15, 1249-1254.

Stine, G. J. \& ClARK, A. M. (1967). Synchronous production of conidiophores and conidia of Neurospora crassa. Canadian Journal of Microbiology 13, 447-453.

Werss, B. (1963). An electron microscope and biochemical study of Neurospora crassa during development. Journal of General Microbiology 39, 85-94.

ZaLOKAR, M. (1959). Enzyme activity and cell differentiation in Neurospora. American Journal of Botany 46, 555-559. 